BULLETIN Bulletin hispanique

HISPANIQUE Université Michel de Montaigne Bordeaux

113-1 | 2011

Actes de 2 colloques

\title{
El romance entre poetas, críticos y libros de poesía en los albores de la modernidad
}

Tres calas y algunos sondeos

\section{Giuseppe Di Stefano}

\section{(2) OpenEdition \\ Journals}

Edición electrónica

URL: http://journals.openedition.org/bulletinhispanique/1332

DOI: 10.4000/bulletinhispanique.1332

ISSN: 1775-3821

\section{Editor}

Presses universitaires de Bordeaux

\section{Edición impresa}

Fecha de publicación: 1 junio 2011

Paginación: 129-162

ISBN: 978-2-86781-740-3

ISSN: 0007-4640

\section{Referencia electrónica}

Giuseppe Di Stefano, «El romance entre poetas, críticos y libros de poesía en los albores de la modernidad », Bulletin hispanique [En línea], 113-1 | 2011, Publicado el 01 junio 2014, consultado el 19 abril 2019. URL : http://journals.openedition.org/bulletinhispanique/1332 ; DOI : 10.4000/ bulletinhispanique.1332 


\title{
El romance entre poetas, críticos y libros de poesía en los albores de la modernidad. Tres calas y algunos sondeos
}

\author{
Giuseppe Di Stefano \\ Università di Pisa - Italia
}

L'article répertorie et commente les modalités et les limites de la persistance de la forme "romance» dans la culture littéraire du XVIII siècle, chez les poètes, les critiques et les auteurs d'anthologies.

Se rastrean y comentan modos y límites de la persistencia de la forma "romance» en la cultura literaria del siglo XVIII, entre poetas, criticos y antologistas.

This article lists and comments upon the modes or limits of the persistence of the "romance " form in the literary culture of the eighteenth century, among poets, critics and the authors of anthologies.

Mots-clés : Romancero - Littérature du XVIII ${ }^{\mathrm{e}}$ siècle.

$\mathrm{E}$ $\mathrm{N}$ las páginas siguientes se comentan materiales y datos que creo significativos no por ser desconocidos sino porque van cotejados entre sí según una perspectiva muy circunscrita y concreta: la suerte del que las protagoniza, el romance octosilábico. No se excluyen del todo sus múltiples variedades pero sí el romancero vulgar o de ciego, tan corriente sobre todo

Bulletin Hispanique, Tome 113, nº 1 - juin 2011 - p. 129 à 162. 
desde el siglo XVII en otros niveles de la producción y del consumo, como las jácaras, cuyo lenguaje y tono gozaron en el XVIII de ocasionales favores entre letrados para sustentar lo hiriente de alguna polémica.

\section{LOS POETAS}

Es opinión corriente que «Mediado el siglo XVII se inicia la decadencia [del romance], y en el XVIII el romance llega a su índice de creación más bajo»; y también que el romancillo «En el siglo XVIII fue ignorado por largo tiempo; en el último tercio, sin embargo, experimentó un reflorecimiento como consecuencia del nuevo auge del género anacreóntico, impulsado por Meléndez Valdés y por Cadalso, y entonces se convierte en la forma básica de numerosas odas anacreónticas, letrillas, idilios, cantilenas y romances menores»; y en fin, que el romance heroico «En las obras de los poetas neoclásicos es la forma predominante en la tragedia y el poema épico» ${ }^{1}$. La opinión parece confirmada nada más ojear dos enjundiosas antologías de la poesía del siglo XVIII publicadas dentro de dos prestigiosas Colecciones de clásicos españoles, la de la Editorial Castalia y la de la Editorial Cátedra: en la primera encontramos solamente 4 romances, dos de los cuales son de Meléndez Valdés, y 5 en la segunda.

Alguna disconformidad con la opinión corriente ha sido manifestada. «Pese a las nociones vulgares y los juicios expresados en los manuales, los neoclásicos españoles casi siempre se esforzaban por armonizar sus obras tanto con la herencia espańola como con la tradición occidental en general», escribe Sebold; y agrega: «Esto es evidente por el frecuente uso en el teatro neoclásico de las formas métricas nacionales, como el romance de versos octosílabos y el romance heroico o real, esto es, el compuesto de versos endecasílabos ${ }^{2}$. Es la recuperación muy oportuna del ancestral romance octosilábico, que puede encontrar su confirmación en la magna recopilación de poetas del siglo XVIII realizada por Cueto, donde el número de romances octosilábicos supera el par de centenares y donde bien se aprecian las múltiples variedades y subespecies métricas que suelen caer bajo la denominación de romance, especialmente el romance de siete sílabas, afortunadísmo desde

1. Rudolf Baehr, Manual de versificación española, Madrid, Gredos, 1970, p. 216, 221 y 223.

2. Russell P. Sebold, Cadalso: el primer romántico 'europeo' de España, Madrid, Gredos, 1974, p. 260. 
las anacreónticas de Luzán a las de Cadalso y demás ${ }^{3}$. Entre los metros más usados por Iriarte en sus Fábulas domina el de la oda, pero le sigue el romance.

En cuanto a Meléndez Valdés, sabemos que «En sus ediciones y en las colecciones manuscritas [...] ordenó sus composiciones según criterios genéricos y métricos, siendo los grupos más importantes las odas anacreónticas [...], los romances [...], y las odas [....] De menor importancia numérica son las letrillas, los sonetos, las elegías, las silvas, las éclogas y las epístolas» ${ }^{4}$; y tengamos en cuenta que un texto denominado Oda es en verso de romance octosilábico y lo mismo un Discurso. De esa Oda comenta Menéndez Pelayo: «sin temor a las detracciones de los preceptistas, elevó el romance a la majestad lírica en el suyo de La tempestad, que se atrevió a llamar oda, con escándalo del bueno de Hermosilla» ${ }^{5}$. Este inconformismo no sorprende en un Meléndez que en 1787 publica su primer poema filosófico, La despedida del anciano, en la forma del romance, del todo impropia para tal tema según la teoría; un Meléndez que «ocupó su estancia forzosa en Madrid [1808] escribiendo contra los franceses un romance titulado Alarma española, que obtuvo un gran éxito popular y del cual circularon muchas copias [...], en que Meléndez denunciaba la 'perfidia del corso'»'; un Meléndez que «emplea el romance para una narración histórico-sentimental (Doña Elvira), antecesora del romance histórico cultivado luego por los románticos del siglo XIX", según registra Polt, quien también recuerda que «en esta senda le precedieron Nicolás de Moratín y Vicente García de la Huerta» ${ }^{7}$. Aquel Nicolás Moratín

3. Poetas líricos del siglo XVIII, editados por Leopoldo Augusto de Cueto entre 1869 y 1875, y en los vols. LXI, LXIII y LXVII de la «Biblioteca de Autores Españoles». En el Índice de las poesías publicadas en los periódicos españoles del siglo XVIII, redactado por Francisco Aguilar Piñal, "Cuadernos Bibliográficos», núm. XLIII, Madrid, CSIC, 1981, y que reseña veinticinco publicaciones de 1739 a 1807, entre los textos más numerosos prevalecen los Sonetos, seguidos inmediatamente por las Odas y después por Fábulas y Letrillas, y por Anacreónticas y Romances; bastante distanciados quedan Canciones, Décimas, Octavas y Epigramas.

4. Juan Meléndez Valdés, Poesías selectas. La lira de marfil, ed. de J. H. R. Polt y George Demerson, Madrid, Castalia, 1981, p. 37.

5. Marcelino Menéndez Pelayo, Historia de las ideas estéticas en España, Santander, CSIC, 1940, III, p. 395.

6. Juan Meléndez Valdés, Poesías selectas, cit., p. 20 [Demerson].

7. Ibid., p. 38. Quintana no ahorró elogios a «la sensibilidad y el gusto exquisito de los romances» de Meléndez, apuntando: «hasta en sus últimos días, cuando, anciano ya y quebrantado con la miseria y las desgracias, parecía que su espíritu debía estar poco apto para estos juegos [las composiciones poéticas], se le ve, en el romance del Náufrago, en el del Colorín de Filis, y en la anacreóntica $A$ Anfriso, recorrer las cuerdas de la lira con la misma delicadeza, flexibilidad y gracia que en sus mejores tiempos»; recordaba también el que fue «frívolo recurso», por ingenuo e inútil, del aterrorizado Meléndez: «recitar un romance popular y 
elogiosamente maltratado por Menéndez Pelayo: «este poeta, nacional más que otro ninguno de aquel siglo, y que debe a los restos y desperdicios de la tradición nacional toda su legítima gloria; este inconsciente precursor de los romances históricos y de las leyendas de Duque de Rivas y de Zorrilla, era en teoría el más violento, el más furibundo de cuantos entonces juraban por la autoridad de Boileau» ${ }^{8}$.

A propósito de pasión nacionalista, hay un dato interesante en la experiencia de Meléndez como Fiscal de la Casa de Alcaldes. Llamado a redactar un Informe para proceder a una de las tantas censuras y prohibiciones de los romances de ciegos, al cerrarse ya el siglo XVIII, desarrolla una crítica violenta de tales romances por sus temas, pero predica y pide a las autoridades una actividad de promoción de la forma romance, de noble historia, para asuntos altos y formativos. En efecto constata que tantos «ingenios y poetas españoles amantes de la Nación y la Humanidad» frente al romance «hoy no lo ejecutan por no verse tal vez confundidos con el ciego Lucas del Olmo, sevillano, y otros miserables xacareros que llenan los puestos y tendidos de los romancistas [...]» ${ }^{9}$. No todos los ciegos adolecían de privación de la vista. En los mismos años El Correo de Ciegos, periódico con título humorístico, anunciaba para su vol. VII un apartado dedicado a Poesía, escribiendo: «Pero como hay varios para quienes es lo mismo una oda de Anacreonte o una de Villegas que una mala décima o un romance cualquiera [...]», los textos se publicarán acompañados de un juicio crítico ${ }^{10}$. ¿A qué género de romance se refería y a qué tipo de lector? Es cierto que el romance era un género invadente e inquietante.

Leandro Fernández de Moratín compone tres Odas y un Romance, entre 1784 y 1790. El Romance va dirigido a Floridablanca, "pidiéndole un beneficio eclesiástico", mientras los otros tres textos, Odas, exaltan a Carlos III uno, el nacimiento de los mellizos del futuro Carlos IV otro y el tercero la proclamación de Carlos IV. En una carta de 1784, dirigida quizás a Llaguno, Moratín había pedido ya una intervención para que Floridablanca le asignara una pensión, aduciendo a su propio mérito las Odas. El conjunto de las

patriótico que había compuesto antes del 2 de mayo» - Alarma española, se supone - al populacho que le amenazaba de muerte, en Oviedo: op. cit., infra, nota 16, p. 113, 120 y 118.

8. Op. cit., p. 285-286.

9. Ángel González Palencia, Eruditos y libreros del siglo XVIII, Madrid, CSIC, 1948, p. 208.

10. Apud Inmaculada Urzainqui, «La crítica literaria en la prensa del siglo XVIII. Elementos de su discurso teórico», en Bulletin Hispanique, 102, 2000: Les origines de la critique littéraire en Espagne. XVI-XVIII siècle, p. 519-559 [522]. 
cuatro composiciones documenta una amarga experiencia de adulación magnilocuente para obtener un favor; al mismo tiempo es un interesante testimonio de usos poéticos: el tema serio, alto y solemne, ocupa las Odas mientras un tono chistoso, a trechos bufonesco, sin cesar de ser -en este caso- adulatorio, es el adoptado en el Romance (como en los demás suyos), escrito entre 1788 y 1790 . Un Romance del que se entusiasma el relamido Hermosilla, quien lo juzga "graciosa y delicada composición» y comenta, en un tripudio de exclamativos: «En su género no la tiene mejor nuestro Parnaso ¡Qué felices ocurrencias! ¡Qué decorosa familiaridad! ¡Qué versos! ¡Qué soltura! ¡Qué ligereza! ¡Qué todo! ¡Y esto se escribió jugando! ¡Por un joven, un muchacho, como lo dice él mismo!» ${ }^{11}$

También un intelectual y pedagogo mucho más abierto que un Hermosilla apreciaría ese Romance, incluso por su respeto de los principios de una sana teoría poética. Me refiero a don Alberto Lista, que entra aquí con pleno derecho a pesar de haberse extendido su vida de poeta y maestro a lo largo de toda la primera mitad de Ochocientos. Afirmaba, con humor, José María Jover: "Gran lección de un hombre que, frenado de antemano en toda su juvenil escapatoria por su formación clasicista, paseó con solemnidad indecisa por una centuria que le escuchó seducida, pero que no era la suya, un trozo vivo del siglo XVIII» ${ }^{12}$. Dictaba, en efecto, Alberto Lista:

Tres son los metros más comunes de nuestra poesía: el verso de once sílabas, el de siete y el de ocho. El primero se cree más propio para los asuntos serios y sublimes, ya esté solo, ya mezclado con el de siete. Éste acomoda más a la poesía ligera, graciosa y festiva. El

11. Leandro Fernández de Moratín, La derrota de los pedantes. Lección poética, ed. de John Dowling, Barcelona, Labor, 1973, p. 141 sigs.; en un Apéndice Dowling publica los cuatro poemitas, y vid. p. $164 \mathrm{n}$. Sobre «la imagen de poeta clasicista» que Moratín perfila de si mismo al seleccionar textos y géneros para sus Poesías sueltas, vid. la edición de sus Poesías completas por Jesús Pérez Magallón, Barcelona, Sirmio-Quaderns Crema, 1995, p. 94-98, donde se observa: «Sí es llamativo que, a diferencia de su padre [cuyos romances alaba con fuerza: p. 166], no usara el romance para poemas de tema histórico y en su lugar utilizara el soneto" (p. 96). En realidad usó el romance para La toma de Granada por los Reyes Católicos, su primer texto poético conservado, de 1779 , presentado a un concurso convocado por la Real Academia; pero es un romance atípico, el llamado 'heroico', en endecasílabos: p. 463. De cómo gustara Moratín improvisar 'romanzones' humorísticos y burlescos para divertir a los amigos, da noticia Silvela: pp. 121-122. Pero don Leandro aclaraba: «la poesía graciosa y ligera» es «un género de muy difícil ejecución», dando una lista bien meditada y compleja de «requisitos indispensables» que "cuando en una composición burlesca lleguen a reunirse [...] el que la desprecie merece lástima» (p. 314-315). Vid. también infra, nota 68.

12. José María Jover, «Alberto Lista y el Romanticismo español», Arbor, XXI, 73, 1952, p. 127-136 [134-135]. 
de ocho, aunque muy perfeccionado por nuestros antiguos cómicos, tiene sin embargo demasiada facilidad, ocurre con demasiada frecuencia en la prosa espańola, para que se le juzgue propio de los asuntos graves. Generalmente se aplica a la sátira, a la burla, a los géneros familiares [...] La ligereza del heptasílabo se presta mejor a los asuntos festivos, y la marcha igual y pausada del metro de ocho sílabas a los sentimientos tranquilos y a la expresión familiar de las ideas y sentimientos ${ }^{13}$.

Lista fue también poeta y nada escaso. Ahora bien, no solamente se permitió faltar de respeto a las correspondencias entre formas métricas y materia tratada, sino que más de la mitad de su producción entera, que consta de 548 textos, se presenta en formas populares, sobre todo la de su edad juvenil, o sea cuando estaban todavía ausentes o soplaban menos los aires románticos. Llegan a cubrir también la mitad del total los temas amorosos, que de instinto no tenderíamos a asociar a la lira de Lista. Los romances propiamente dichos son 53 , o sea un $10 \%$ escaso, algunos de tema filosófico y dos hasta de tema fúnebre. El total de poemas de tipo romanceril sube a 115. Una curiosidad conclusiva: el último poema conocido de Lista, escrito a los 72 años, es un romance.

Para cerrar esta selección de poetas, poetas-críticos como la mayoría, dirijamos una mirada a Quintana, otro intelectual prestigioso e influyente, medio dentro y medio fuera de sus tiempos. Menéndez Pelayo es telegráfico y no tan exacto: «fué el poeta de las ideas del siglo XVIII, y por eso enmudeció dentro del XIX», «enmudeció como poeta desde 1829, como crítico y como historiador desde $1830{ }^{14}$. Las fechas cuentan mucho en la biografía de Quintana, como en la de tantos otros protagonistas de las letras y de las batallas de ideas en una época de las más atormentadas de la historia española.

13. Alberto Lista, Ensayos literarios y criticos, Sevilla, 1844, II, p. 5; y en p. 11: los vv. «de 7 y 8 sílabas son en los que más brilla la gentileza y gallardía de las musas castellanas», y vid. José Matías Gil González, Las formas populares en la poesía de Alberto Lista, Sevilla. Diputación Provincial, 1987, p. 126. Ejemplarmente dentro de la norma la obra poética de Jovellanos: en sus setenta y seis composiciones, incluyendo las atribuidas y los fragmentos, los romances son seis: uno es de tema amoroso y los demás son todos burlescos y de polémica literaria, imitando en algunos a los de ciego y en otros a Góngora; vid. Obras completas, I: Obras literarias, ed. crítica, introd. y notas de José Miguel Caso González, Oviedo, Centro de Estudios del Siglo XVIII-Ayuntamiento de Gijón, 1984. Gran admirador de Jovellanos, Quintana sin embargo tenía reservas sobre sus textos poéticos: «Los cortos, sobre todo, están generalmente mal construidos, faltos de gracia, de cadencia y de rotundidad»: op. cit. infra, nota 16, p. 155; en p. 154 juicio bien distinto sobre «los cortos» de Meléndez.

14. Op. cit., p. 409, recogiendo en parte declaraciones del mismo Quintana tajantes en exceso. 
Sobre la base de las Poesías completas de Quintana según la edición de Albert Derozier, notamos de inmediato que - de los setenta textos conocidosson cuarenta y siete los compuestos hasta 1808 y solamente veintitrés los sucesivos, a partir de 1815: encarcelado en Pamplona, compone $A$ Dafne, en sus días. Romance; el texto sucesivo es de 1825, A Licoris, consolándola de una ingratitud. Endechas, un romance hexasílabo; se continúa hasta 1856, un año antes de la muerte, con largos intervalos de silencio poético, según la documentación que poseemos. En la que podríamos llamar la primera época, los romances son tan sólo cuatro mientras en la sucesiva suman a once, o sea casi la mitad de toda la producción de esos años. Siete de ellos son para los Álbumes de distinguidas damas, tres de tema entre pastoril y amoroso, como eran tres de los cuatro de la primera época, y uno más personal y nada frívolo, en el que hallamos la clave del cambio. Es el romance que un Quintana frustrado en sus ideales, y ya sin ilusiones acerca de la situación política, dedica $A$ Somoza en 1826, al amigo poeta que le «escribía lisonjas y esperanzas», según informa en un soneto de pocos meses antes y donde así metaforiza su estado: «Nunca lozana a su primer contento / la planta vuelve que truncó el arado». Así no pueden volver ya «la elegancia y la pompa / con que los hijos de Apolo / dan vida eterna a sus obras [...], imágenes deliciosas, pensamientos grandes, [...] del Genio la sacra antorcha [...], lira de oro / con $s u$ voz majestuosa», las dotes excelsas que dieron inmortalidad a tantos de sus poemas: y recuerda las odas Al Mar de 1798 o A España de 1808: es éste el tema amargo del Romance. Son acentos que vuelven en el romance endecasílabo de 1848 Para el album de la señora marquesa viuda de Cerralbo: «[...] Bien quisiera tener para agradarte / aquel vigor antiguo y aquel fuego / que animaban mi pluma en otros días / y algunos lauros a mi frente dieron"; el tópico de la falsa modestia apenas disfraza una sincera aridez: «y exentos de lisonja yo te ofrezco / versos que en nada tu modestia ofenden, / si es que son dignos de llamarse versos», autocrítica que como fórmula se repite dos años después en otro romance endecasílabo, éste Para el album de doña Concha Martínez de Figueras, recién casada: «[...] id a los pies de Concha, versos míos, / bien poco dignos de llamaros versos.» ${ }^{15}$ ¿Será un caso que estos versos «poco dignos» de llamarse tales sean en ambos textos endecasílabos? Creo que no, como creo que no se trata de fórmula. En unas enjundiosas páginas que habían aparecido al frente de la edición de las Poesías de Meléndez Valdés en 1820, Quintana refería de «la aversión que [Meléndez] tenia al romance endecasílabo, clase de versificación que aborrecía, considerándola

15. Manuel José Quintana, Poesías completas, ed. Albert Derozier. Madrid, Castalia, 1969: los versos citados en p. 345, 347, 349, 350, 385, 386 y 389 . 
como producto del mal gusto del siglo anterior»; años antes, tratando de la decadencia de la poesía en el siglo XVIII precedente a la de Meléndez, Jovellanos y demás, Quintana había criticado sobre todo «el prosaismo y la flojedad», agregando: "Pensaban sus autores que por haber ajustado sus pensamientos en renglones de once sílabas, con alguna cadencia métrica y buenos consonantes al fin, dispuestos en una simetría exacta y puntual, estos renglones eran versos, y ellos, por consiguiente, poetas» (y cfr. infra, Forner y los abusivos del Parnaso); escribiendo sobre la Bética conquistada de Juan de la Cueva, liquidaba una octava como un conjunto de "viles renglones de once sílabas» ${ }^{16}$. Sí, "la lira de oro, con su voz majestuosa» se había ido aflojando cada vez más hasta callar. Amargamente, Quintana habría podido aplicarse al sí mismo de la segunda época las palabras que había dedicado a Esquilache, abortado poeta épico pero elogiado y antologizado en lo demás de su poesía: «Podía el Príncipe dar gracia á bagatelas, discretear en romances, juguetear en endechas y en letrillas; pero...Sectantem levia nervi / Deficiunt animique» ${ }^{17}$. Quintana se siente el príncipe decaído de los géneros poéticos «que exigen mucha elevación de alma, gran vuelo de fantasía, viveza en la expresión de los afectos, gala y fuerza en los colores, número y flexibilidad en los sonidos» ${ }^{18}$ : esto lamenta, por vía bastante directa, en $A$ Somoza y esto sobre todo manifiesta en su actividad poética de la segunda época, con el fuerte predominio de la ligera poesía de ocasión y en particular de romances y hasta de once sílabas. Habrá influído, por cierto, el auge del romancero a lo largo de los primeros decenios del siglo XIX y el haber Quintana mirado al romance siempre con interés y aprecio, como afirma Derozier ${ }^{19}$ y como se va viendo en estas páginas; pero en ellas se ve también a las claras el grado que Quintana asigna al género en la escala de valores del arte de la poesía, escala que era la de su formación dieciochesca, aunque con aquellas aberturas y sensibilidad que incluso en su 'decadencia' le permiten darnos una joya, $L a$ Fuente de la Mora Encantada, de 1826, un romance en que se concede -o mejor, concede a lo nuevo que urge- algún arcaísmo lingüístico, casi la fabla de una antigua moda romanceril. Sobre Quintana y el romancero se volverá en la tercera cala, la dedicada a los libros de poesía.

16. Manuel José Quintana, Obras completas, vol. XIX de la «Biblioteca de Autores Españoles» (1851). Madrid, Atlas, 1946: las tres citas respectivamente en p. 111, 152 y $164 n$.

17. Ibid., p. 173.

18. Ibid., p. 151.

19. Manuel José Quintana, Poesías completas, cit., p. 21, 26 y 351n. 


\section{LOS TEÓRICOS Y CRÍTICOS}

Emilia de Zuleta supone acertadamente en Luzán una positiva «valoración indirecta de los romances cuando opina que la asonancia es una forma de versificación con grandes posibilidades» ${ }^{20}$. La página de La Poética aludida tiene un interés ulterior y diría mayor. Leámosla.

$\mathrm{Al}$ acabar de citar la forma métrica del texto de Alfonso X «Poderá Sancta María», Luzán agrega:

Añadiendo a esta especie de coplas más versos que desde el principio al fin siguiesen el mismo consonante en los pares, quedando sueltos los nones, resultaba un romance corto, como generalmente lo eran los antiguos, que, sin duda, se inventaron para cantar lances de amor y de caballería, así por la facilidad de sus metros, como por acomodarse mejor a la música ruda de aquellos tiempos y aun al baile; pues en las montańas, particularmente en Asturias, se usan todavía para cantar en el baile que llaman danza prima, intercalando un estribillo entre cada copla de cuatro versos ${ }^{21}$.

Este relámpago de folklore asturiano dentro del áulico tratado es sorprendente tal cual fue la cita de los romances en el Prohemio y Carta del marqués de Santillana; con la diferencia que ahora se remite a poesía de rústicos para ejemplificar una modalidad métrica, o sea una norma, y no para censurar la ausencia de toda norma según ocurría en el Prohemio. Hay más. Sabemos todos que como testimonio más antiguo de la danza asturiana asociada al canto de un romance suele citarse una carta de Jovellanos a Antonio Ponz escrita alrededor de 1782, no utilizada por Ponz, y acaso modificada por Jovellanos entre 1789 y 1797 en vista de una publicación que no se efectuó ${ }^{22}$. La primacía de esta noticia tendríamos que trasladarla

20. Emilia de Zuleta, «La literatura nacional en las Poéticas españolas», Filología, XIII, $1968-69$, p. 397-426 [406].

21. Ignacio de Luzán, La poética o reglas de la poesía en general, y de sus principales especies, ed. de Russel P. Sebold, Madrid, Cátedra, 2008, p. 412.

22. Ramón Menéndez Pidal, Romancero hispánico. (Hispano-portugués, americano y sefardi). Teoría e historia, Madrid, Espasa-Calpe, 1953., II, 375-377 y Jesús Antonio Cid, Silva Asturiana, I: Primeras noticias y colecciones de romances en el s. XIX, Madrid, Fundación Menéndez Pidal y otros, 1999, p. 24, con ed. parcial. Supone la modificación entre 1782 y 1794 José Caso González, ed., Gaspar Melchor de Jovellanos, Obras en prosa, Madrid, Castalia, 1969, p. 31; pero tiende a excluirla en su ed. de las Cartas del viaje de Asturias, Guijón, Ayalga, 1981, vol. I, p. 49; en su Vida y obra de Jovellanos, s. 1., Caja de Asturias-El Comercio, [1993], sobre las cartas asturianas escribe en la p. 137: «en Gijón las corrigió ampliamente entre 1794 y $1796 »$, mientras en la p. 152 admite, para la carta en cuestión: 
al texto de Luzán, con todo lo que puede significar el atribuirla no a una carta que reunía información sobre usos y cultura populares regionales sino a un tratado de forma y materia eminentemente altas y cultas. Sin embargo, asoma un problema.

El remite a la danza prima se encuentra en el capítulo XXIII del Segundo Libro de La Poética, uno de los que se ańadieron en la segunda edición de la obra, aparecida en 1789 , o sea siete años después de la redacción y probable envío de la carta de Jovellanos. Podríamos descuidar tal circunstancia si no existieran dudas sobre la autoría del texto de esos ańadidos. Como es sabido, Luzán había ido apuntando modificaciones e integraciones sueltas a su Poética en un ejemplar propio de la primera edición, de 1737, y había redactado en papeles aparte los que iban a ser capítulos enteramente nuevos. Su discípulo y amigo Llaguno tuvo tales materiales entre manos y con ellos empezó a preparar en 1783 la segunda edición de la Poética. De ello avisa Llaguno en el Prólogo, pero añadiendo de soslayo una alusión a algún aporte propio, 'generosamente' sin distinguirlo del texto de Luzán. Conocemos pareceres y discusiones de los especialistas sobre el asunto y sabemos que -obviamente- no se ha llegado a un acuerdo. Incluso el que mejor argumenta una autoría de Luzán prácticamente integral para los añadidos, acaba remitiendo al deseable hallazgo de los materiales de don Ignacio para alcanzar la respuesta definitiva a las dudas ${ }^{23}$. Para el punto que nos interesa, me inclino a considerar la cita de La Poética independiente de la carta de Jovellanos: vid. infra el Apéndice.

Interesa subrayar ahora la atención informada, y aséptica diría, con que Luzán trata el punto en un contexto técnico, el capítulo sobre consonantes, asonantes y versos sueltos, aduciendo un ejemplo de curiosa supervivencia de una forma métrica antigua asociada al canto en la danza. Gracias al testimonio oral contemporáneo se enriquece el documento antiguo escrito, aportándose el estribillo, notoriamente omitido en manuscritos e impresos del XV, XVI y XVII con romances viejos tradicionales. Además, a la cita de la danza asturiana sigue una precisación: «Pero no era esta composición de versos en rima alternados con versos sin ella la única que se llamaba romance» y se remite a romances del Cancionero General, a uno de Garci Sánchez de Badajoz excéntrico respecto al uso más corriente de «una sola

«todo hace pensar que no la corrigió», remitiendo justamente a lo que anotaba Jovellanos el 31 de julio de 1797 en sus Diarios: «Repaso de la Carta sobre las romerías: necesita mucha corrección para publicarse, y no hay tiempo para dársela»: ed. de Julio Somoza, Oviedo, Insituto de Estudios Asturianos, 1954, II, p. 370.

23. Me refiero a Sebold: vid. el cap. VI de su Introducción a la ed. cit. de La poética de Luzán. 
rima seguida desde el principio al fin en los versos pares», con otro ejemplo de Quirós y uno de Timoneda. Luzán da relieve al progresivo abandono de la consonancia hacia finales del siglo XVI y a la recuperación de una asonancia más refinada respecto a la antigua, y gracias a la cual «ganamos una versificación excelente para varias composiciones que, como ya dije, es propia y peculiar de nuestra lengua" y que fue extendiéndose a metros más cortos, como los heptasílabos: y cita aquí un segmento de su «idilio de Leandro y Hero» ${ }^{24}$. Más adelante, tratando del teatro, afirma: «en cuanto a los versos de romances [octosílabos] con asonantes, me parece que son muy proprios de la comedia, por ser muy semejantes a la prosa ${ }^{25}$. En efecto, para Luzán «Es preciso [...] que el poeta, conformando la sentencia y la locución a la calidad de las personas y del asunto, dé a la comedia un estilo llano, puro, natural y fácil ${ }^{26}$, serie de adjetivos que volveremos a encontrar en tantas frases dedicadas a los romances a lo largo del siglo y en el siguiente. El favor de Luzán hacia el octosílabo, el romance y la asonancia es indiscutible; salvando límites, obviamente: «romances y décimas y otras composiciones en versos cortos, en los cuales es cierto que nuestros poetas han manifestado singular ingenio y agudeza extremada; pero la grandeza de la verdadera poesía no cabe en tan pequeños límites, y solo puede enteramente lucir en los grandes poemas, en los dramas y en las poesías líricas de mayor extensión ${ }^{27}$.

A la comedida abertura de Luzán, en particular hacia el metro de romance en la comedia, da relieve el rechazo de un Hermosilla en su Arte de hablar en prosa y verso (1825), ya en el otoño de las poéticas neoclásicas. Para este maestro institucional de arte retórica en los primeros decenios del siglo XIX, obsesionado por las jácaras y las tonadas populares, por «los copleros y los poetas canijos» (II, p. 184), una de las razones que hacían despreciable el romance era propiamente el haber sido usado en la comedia. Para Hermosilla el romance quedaba ya excluido de cualquier posibilidad de redención: «este metro se ha hecho vulgar, se ha envilecido, no hay ya medio de ennoblecerle» (II, p. 176) ${ }^{28}$. Será el Duque de Rivas, con sus Romances y el Prólogo anejo, quien al poco tiempo echará abajo tal furia. Antes se habían pronunciado Durán, con un buen comentario del Angélica y Medoro, el romance gongorino ya unánimemente apreciado en el siglo XVIII, y Martínez de la Rosa, que en

24. Ignacio de Luzán, La poética, cit., p. 412-414.

25. Ibid., p. 571; en la ed. de 1789, además de lo que va entre corchetes, se omite "por ser [...]" y se coloca este refuerzo: "y que con ellos pudiéramos excusar todas las demás especies», p. 572.

26. Ibid., p. 591.

27. Ibid., p. 173.

28. Las citas de Hermosilla apud Emilia de Zuleta, cit., p. 415. 
las densísimas notas a su Poética (1827), donde no faltan ecos quintanianos y de otros predecesores, escribe: «La poesía más común en España, la que merece más bien el nombre de nacional, es el romance asonantado», resaltando en largos párrafos como títulos de mérito la aceptación popular y su uso en el teatro, y subrayando: «el romance es propiamente la poesía lírica de los españoles ${ }^{29}$ (lo afirmaba ya Quintana, y había antecedentes). Por otro lado Hermosilla no era solo, al comienzo del XIX, en dar brillo involuntario al equilibrio ponderado y a la abertura de Luzán. Le hacía buena compañía el Manuel María de Arjona del Plan para una historia filosófica de la poesía española (en Correo de Sevilla, 1806), quien excluía a los poetas anteriores a Garcilaso «y a todos los que en el siglo XVI metrificaron imitando, ya las formas populares, ya las de los últimos poetas del siglo anterior ${ }^{30}$.

Tampoco Luzán fue único en sus años. En teorizar como estudioso abierto a una evaluación equilibrada de los documentos y bien atento a la perspectiva histórica y a los contextos, podemos asociarle Gregorio Mayans, sin duda a él superior en erudición y afán casi enciclopédico, un Mayans «que nunca fue un neoclásico, sino un eximio representante del humanismo tardío y el hombre que más y mejor se embebió en su tiempo de la literatura española áurea» ${ }^{31}$.

Empecemos con dos pequeños ejemplos, dentro de nuestro tema. En $E l$ orador christiano, de 1733, al tratar de las descripciones físicas de las personas en poesía, informa que "en los entremeses, sátiras i vejámenes que se estilan en las academias, se ofrecen egemplos sin número" y cita la primera pareja de versos de un Romance de Antonio de Solís; pero también avisa que «semejantes descripciones más convienen al theatro que al púlpito; son propias del corral, no de la Iglesia» ${ }^{32}$. Como en Luzán, se señalan límites y licitud en relación con los contextos. La exhaustividad detallista de Mayans va más allá, como su tolerancia y su conciencia de lo que es una convención respecto a la realidad. Tratando de los vocablos «que únicamente usa el vulgo, aunque no signifiquen cosas viles, se tienen por viles», avisa que tales «son en gran parte las voces que recogió don Francisco de Quevedo Villegas en su Cuento de cuentos; de donde tomó algunas don Antonio de Solís, en

29. Francisco Martínez de la Rosa, Obras, Madrid, Atlas, 1962, II: B. A. E., vol. CIL, p. 292 sigs. y 319 sigs.

30. Marcelino Menéndez Pelayo, op. cit., p. 441-443.

31. François Lopez, «Sobre los géneros y otros conceptos de la crítica en la España moderna», Bulletin Hispanique, n. 1, 2004: Penser la Littérature Espagnole, p. 317-350 [320].

32. Gregorio Mayans y Siscar, El orador christiano, en Obras completas, II: Literatura, Valencia, Ayuntamiento de Oliva - Diputación de Valencia, 1984, p. 67. 
el romance que empieza: Érame yo Inés antaño, i en el otro que empieza: Añasquillo el de Segovia»; y añade: "También se deven contar entre las voces viles las del idioma de los pícaros que llaman jacarando» y da una serie de términos, remitiendo una vez más al «ingeniosíssimo Quevedo» ${ }^{33}$. No hay censuras sino géneros y sus convenciones.

Mayans lo confirma en la Vida de Cervantes, de 1737, cuando escribe:

para que no nos faltasse alguna idea de la fábula sáltica, si es que deve llamarse assí la que se dice que inventó o a lo menos compuso nuestro español Lucano, [Cervantes] nos le dejó en La gitanilla i en La ilustre fregona, como también de la psáltica que podemos llamar cantar o romance, de cuya especie compuso, según él dice, infinitos, entre los cuales avría muchos ciertamente correspondientes a la grandeza de su ingenio, i yo (aunque por congetura) pudiera aquí señalar algunos i especialmente el que empieza En la corte está Cortés, que me agrada mucho $^{34}$.

En su poderosa Rhetórica, de 1757 (reeditada, con retoques, en 1786), volverá a citar el mismo romance, con tres versos más, para ilustrar la paronomasia o annominatio ${ }^{35}$.

La Rhetórica de Mayans es, entre otras cosas, un formidable archivo de citas, superior en su siglo a cualquier otra obra del mismo género por número de autores y textos aprovechados ${ }^{36}$. Con la Poética de Luzán forma «las dos columnas de la preceptiva literaria del siglo XVIII» ${ }^{37}$. La materia de nuestro interés se presenta con una muy larga cita del Romance de Torres Naharro

33. Ibid., p. 95.

34. Gregorio Mayans y Siscar, Vida de Miguel de Cervantes Saavedra, en Obras completas, II, Literatura, cit., p. 294. Sus catorce ediciones hasta 1782 autorizan a François Lopez a declararla «uno de los éxitos editoriales del siglo»: «Sobre los géneros», cit., p. 350.

35. Gregorio Mayans y Siscar, Rhetórica, en Obras completas, III: Retórica, Valencia, Ayuntamiento de Oliva - Diputación de Valencia, 1984, p. 468.

36. José María Pozuelo Yvancos y Rosa María Aradra Sánchez, Teoría del canon y literatura española, Madrid, Cátedra, 2000, p. 213. «Mina de oro» la define Jesús Gutiérrez en su Introducción a la ed. cit., p. XXV, donde apunta las deudas de Mayans con tratados anteriores, en particular con la Agudeza y arte de ingenio de Gracián; y François Lopez subraya: «Ha venido considerando la erudición este voluminoso libro como la más copiosa antología de la literatura española que llegó a ver la luz antes del siglo XIX", constatando que en lo cumplido de esa muestra «se anticipó a todos los autores de antologías de la literatura espańola»: «Sobre los géneros», cit., p. 339 y 348, y vid. también del mismo «La insitución de los géneros literarios en la España del siglo XVIII», Bulletin Hispanique, 102, 2000: Les origines, cit., p. 473-517 [ 507 y 514-516].

37. Marcelino Menéndez Pelayo, op. cit.. , p. 233. 
sobre la muerte de Fernando el Católico, cuyo exordio es «una suspensión muy tierna, que dice assí: Nueva voz, acentos tristes»; «el fin desta figura, o la salida del discurso que con ella se da, -agrega- deve ser o muy grave, o ligera y graciosa", y transcribe dos poemas de Luis de León ${ }^{38}$. El género romance se encuentra rescatado de su destino para materia ligera y festiva, por lo menos en alguna ocasión. Y en esto no es avaro, Mayans. Porque poco más adelante, a propósito de otra figura retórica, leemos: «Vemos unidos los egemplos de la pleonasmo gramática i rhetórica, en lo que se dice en un antiguo romance:

De los sus ojos llorando,

I de la su boca diciendo,

La pleonasmos gramática consiste en los artículos los i la; i la rhetórica en las palabras ojos i boca» ${ }^{39}$, donde los versos del romance viejo tradicional se merecen su pequeña dosis de comentario. Si es obvio encontrar unas estrofas de un romance de Góngora, mucho menos obvio es encontrar, ilustrando la misma figura, amplias citas de los poetas cancioneriles de finales del siglo XV, Juan Manuel y Puertocarrero ${ }^{40}$. La fuente casi segura era el Cancionero general de Hernando del Castillo, bien conocido y apreciado a lo largo del siglo XVIII y hacia el cual Mayans fue el primero en llamar la atención, según Menéndez Pelayo ${ }^{41}$. Y si no sorprende topar otra vez con versos de un Romance gongorino, «Tengo amigos los que bastan / Para andarme siempre solo», como ejemplo de pensamiento «inconsiguiente» [con la cursiva de figura retórica $]^{42}$, algo sorprende que para la paragoge escoja, entre otros, los versos de Gregorio Silvestre «Majadero sois, amigo, / no merecéis culpa, non», una contrahechura del «Mensajero eres» del romance viejo de Fernán González; pero mucho más sorprenden las citas sucesivas: «I un cantarcillo antiguo: Meteros quiero monja, hija mía de mi corazón, / Que no quiero yo ser monja non. I estotro: Yo me iva, madre, a Villa-Reale, / Errara yo el camino en fuerte lugare. I en el romance del conde de Irlos: $O$ esforzados cavalleros, I De mi dolor haved pesare»" ${ }^{43}$. Todo admirador del romancero viejo y de la antigua lírica tradicional no puede no agradecerle a don Gregorio estas citas

38. Gregorio Mayans y Siscar, Retórica, cit., p. 404-405.

39. Ibid., p. 433.

40. Ibid., p. 456.

41. Op. cit., p. 269. Intermediaria pudo ser la Agudeza gracianesca, que proporcionó citas a Mayans.

42. Gregorio Mayans y Siscar, Rhetórica, cit., p. 644. En El Orador christiano, cit., p. 89-90 había exaltado lo «inimitable» del estilo «natural» y «gallardo» en los romances y en las letrillas de Góngora.

43. Ibid., p. 482. 
dignificantes. Una información al margen: el único portador de buen número de romances juglarescos que pasó del siglo anterior al XVIII fue la Floresta de Tortajada; se reimprimió por lo menos seis veces (vid. infra) y contiene el Romance del Conde Dirlos, difundido asimismo en pliegos sueltos.

Mayans suele citar también refranes, «en la línea del erasmismo español», se ha observado ${ }^{44}$, y cuidó una edición de los reunidos por Santillana; una fuente pudo ser también el Gracián de la Agudeza ${ }^{45}$, bien leido aunque sin entusiasmos. Aduce los romances viejos siguiendo una tradición hispánica representada por el Tesoro de Covarrubias y no descuidada por el Diccionario de Autoridades. Todo este material popular tradicional en verso y prosa había entrado a formar parte de los «ejemplos de los más elocuentes españoles», según Mayans escribía a Burriel en enero de 1754; y éste exaltaba la «abundancia, propiedad y hermosura de los ejemplos» ${ }^{46}$. Muy oportunamente se ha dado relieve al «recurso sistemático a los mejores escritores en lengua castellana, a quienes [Mayans] selecciona y depura desde una óptica a la vez clasicista y pragmática ${ }^{47}$. Debemos a esta ladera pragmática el aporte de los materiales que acabo de registrar; coadyuvada por la inteligente flexibilidad de la óptica clasicista.

Inflexibilidad, por el contrario, quiere ostentar Juan Pablo Forner. Nos deja indiferentes su referencia a un romance juglaresco, cuando escribe: «para el que no lee con otro intento que con el de hablar mal, lo mismo es la geografía que las coplas de Calaínos» ${ }^{48}$, donde Calaínos con sus coplas o romance era un modismo corriente para indicar algo sin valor alguno. La presencia de romances en su producción poética, e incluso en las Exequias (1795) -dos heptasilábicos, dos de once sílabas, uno de seis y solamente uno de ocho-, atenúa poco lo rotundo de la siguiente afirmación: uno de los que han conseguido penetrar en el Parnaso por "no sé qué senda desconocida, y subiendo sin resistencia, vencieron la cumbre a traición», frente a su sorpresa sostiene el derecho propio a estar al lado de Garcilaso alegando: «hago coplas, que llamo versos», ya que el toledano «hacía versos también», y considerando que "La poesía, ¿acaso se reduce a otra cosa que a formar décimas, seguidillas, liras, octavas reales y romances de arte mayor y

44. Jesús Pérez Magallón, En torno a las ideas literarias de Mayans, Alicante, Instituto de Cultura Juan Gil-Albert, 1991, p. 151.

45. Ibid., p. 112 n.

46. Ibid., p. 109 y 127.

47. Ibid., p. 118.

48. Juan Pablo Forner, Exequias de la lengua castellana, ed. de Marta Cristina Carbonell, Madrid, Cátedra, 2003, p. 205. 
menor?» ${ }^{49}$. A propósito del Teatro crítico de Feijóo, Forner recuerda que «La primera cosa que condenaron en él fué haber caído frecuentísimamente en versos octosílabos, que llevan su oración como cojeando sobre las muletas de la mensuración poética» ${ }^{50}$.

Este menosprecio del octosílabo y la anterior referencia a las coplas de Calaínos nos llevan a pensar en varios renglones del padre Sarmiento de espesor bien distinto, en sus Memorias para la historia de la poesía y poetas españoles, aunque debamos retroceder de un par de decenios en cuanto a la fecha de publicación, 1775 (póstuma), y hasta 1745 como fecha en que fue concluida la obra. Escribía Sarmiento: «el de ocho sylabas es el [metro] mas famoso, mas antiguo, mas natural, y mas comun»; agregaba: «insisto en que es el mas connatural, y congénito, que tenemos los Españoles; y que de tiempo inmemorial, hasta hoy, se usa en Espańa este género de verso" ${ }^{51}$. Por lo que atañe a las coplas de Calaínos, por cierto Sarmiento no contradice la opinión negativa tradicional y que se refleja en la cita de Forner; pero la motiva, dentro de interesantes párrafos sobre romancero, que muy probablemente se resienten del espacio que a este género había dedicado el obispo Huet en su Lettre sur l'origine des romans de 1670, bien conocida y seguida en España. Las coplas de Calaínos, nos dice Sarmiento, son «ridículas»; resume su disparatado contenido e informa:

Esta aventura se contiene en unas coplas viejas, y chabacanas, que comienzan: Ya cavalga Calainos; y se hallan en un librito que comprehende varios Romances de este género á los doce Pares de Francia; y es el libro que mas saben de memoria los rústicos, y niños [...] el Poeta, ó Poetas que compusieron estas Coplas, ó Romances, imitaron un antiguo estilo $[\ldots]^{52}$.

Es acertada la evaluación del texto del Romance como tardío, esencialmente por lo fabuloso de su contenido; pero más acertada aun es la referencia al «antiguo estilo» que tales poemitas imitan, o sea el del romancero viejo. El «librito" al que se remite es, sin duda, la Floresta de Tortajada (vid. infra), una de las poquísimas recopilaciones del siglo XVII sobrevivida en el XVIII, con seis ediciones entre 1711 y 1764 : dedicada casi por entero a romances juglarescos de tema carolingio, contiene el de Calaínos.

49. Ibid., p. 213.

50. Ibid., p. 285.

51. Sigo la ed. de Buenos Aires, Emecé, 1942, p. 122 y 124.

52. Ibid., p. 165 y 166. 
Sarmiento continúa: en los «remotos siglos del idioma Castellano» todo género de poesía

ó era Lyrico, ó Heroico en el asunto. Al primero deben reducir todas las coplillas, y canciones del pueblo [...] Estas las supongo anteriores a todos los Romances, cuyo asunto es pintar las aventuras caballerescas, ó amorosas, ó mezcladas, de los heroes, ó verdaderos, ó fingidos, qual es la de Calaínos. De este género son los Romances Castellanos que andan en mano de los rústicos, y hablan de los doce Pares de Francia, de Bernardo del Carpio, y de algunos Aventureros Mahometanos ${ }^{53}$.

Muchos de tales textos -agrega- «andan impresos, y aún se conservan en boca de los rústicos»; han sido aprovechados por autores de poemas épicos de finales del siglo XVI sobre Bernardo o sobre el Cid, aportando a veces materia engañosa por inventada: en efecto, "aunque han dado algun ayre de valor a nuestra Poesía, han hecho mucho daño á nuestra Historia», en particular los de tema carolingio ${ }^{54}$.

Quedan tres parrafillos más dedicados por Sarmiento a los romances, ahora en particular a los del Cid: «La sola colección que he visto, contiene ciento y dos Romances en estilo antiguo, y en versos de ocho sylabas. Leílos todos y observé que estan coordinados segun la vida, y muerte del Cid, y muy conformes á lo que de él refieren la Chrónica particular, y la general». Sarmiento no cae en la cuenta que la bien notada conformidad de romances y Crónicas se debe al haber sido éstas las fuentes de la grandísima mayoría de los que ha leído en la "colección" que cita sin nombrarla, y que es la de Escobar, con siete reimpresiones entre 1702 y 1757 (vid. infra).

Interés más subido tienen sus consideraciones sobre la edad de los romances en general, según los textos que conocemos:

Creo sí, que pocos años después [de haber vivido los héroes cantados] se compondrian varios Romances en su elogio; y serian los que los Copleros, Trobadores, y Juglares, ó Joglares, y generalmente todos los plebeyos cantarian en sus fiestas. Estos se perdieron, porque no se escribian; y los que pudo conservar la tradicion oral, y la memoria, estarian ya tan alterados quando se comenzó a escribir el vulgar Castellano, que no se parecerian a los primitivos en el lenguage; pero muy conformes en lo substancial [...]

53. Ibid., p. 168.

54. Ibid., p. 169-170. 
y se alegan los remites de las Crónicas a los juglares ${ }^{55}$. Con su clara distinción como secundarios de los textos conservados y su referencia a oralidad y memoria, estos renglones parecen esbozar lo esencial del que será, en el siglo $\mathrm{XX}$, el neo-tradicionalismo aplicado a la historia antigua del romancero, incluso con el término "primitivos" para designar los textos más remotos y acaso originarios.

\section{LOS LIBROS DE POESÍA ANTOLÓGICOS}

Llegamos a la tercera cala, la pertinente a las antologías poéticas, a las recopilaciones -en el caso nuestro- dedicadas al romancero o que incluyen un número significativo de romances entre las demás formas poéticas. Es imprescindible tener una idea previa de la fortuna editorial y del decaer progresivo de tales libros antes del siglo XVIII. Nos hará de guía el Manual de Cancioneros y Romanceros de Rodríguez Moñino, que señala el recorrido editorial hasta comienzos del siglo XIX, tocando a veces el XX, para las recopilaciones fraguadas en los siglos XVI y XVII ${ }^{56}$. Y con las de este siglo último empezaré, avisando que tengo en cuenta también las ediciones sin ejemplares conocidos y que, en esta materia, hallazgos o cancelaciones están siempre al acecho.

a. En primer lugar constatemos que en el siglo XVII, según el citado Manual, resultan reimpresos solamente 2 de los 72 libros de poesía con romances aparecidos en el siglo XVI, el siglo de la gran difusión impresa del romancero en todas las fórmulas editoriales y en toda la variedad de sus temas y lenguajes poéticos. Los dos libros fueron:

1. Silva de varios romances, Barcelona 1561.

4 eds. más en el siglo XVI, 13 hasta 1645 y 15 entre 1657 y 1696 , ocho de las cuales entre 1671 y 1675 ; en total tuvo 33 ediciones en siglo y medio.

2. Cancionero llamado Flor de enamorados, Barcelona 1562.

1 ed. más en el siglo XVI y 6 en el siguiente, hasta 1681.

55. Ibid., p. 171.

56. Antonio Rodríguez Moñino, Manual bibliográfico de Cancioneros y Romanceros, (Impresos, s. XVI), 2 vols., Madrid, Castalia, 1973; (Impresos, s. XVII), 2 vols., Madrid, Castalia, 1977-78. 
Ambos libros tuvieron una reducción progresiva de los pocos romances viejos que contenían y un aumento de los nuevos.

b. De las 46 recopilaciones con romances que vieron la luz en el siglo XVII (y vid. también el apartado c), se reimprimieron o imprimieron por vez primera en su segunda mitad, y en ella concluyeron su vida, las siguientes:

1. Breve deleitación de romances varios [...] sacados de diversos autores [...] compuestos por Francisco de la Torre. s. 1. ¿1605? 2 eds. más hasta 1668.

2. Primera parte del Jardín de amadores, en el qual se contienen los mejores y más modernos romances [...] recopilados por Iuan de la Puente, Zaragoza y Barcelona 1611.

3 eds. más hasta 1679.

3. Valdivielso, Primera parte del romancero espiritual. Toledo 1612. 19 eds. más hasta 1681.

4. Primavera y flor de los mejores romances [...] recogidos de varios poetas [...] por Pedro Arias Pérez. Madrid 1621.

17 eds. más hasta 1659.

5. Segunda parte de la Primavera y flor de los mejores romances [...] recopilado de diversos autores por Francisco de Segura. Zaragoza 1629.

3 eds. más hasta 1659.

6. $\quad$ Romances varios de diversos autores. Valencia 1635.

14 eds. más hasta 1664 .

7. Poesías a lo divino [...] por una Religiosa. Madrid. s. a.

1 ed. más en 1671.

8. Xácaras y Romances varios [...] compuestos de diversos autores. Zaragoza 1663

1 ed. más en 1668.

9. Delicias de Apolo. Recreaciones del Parnaso [...] hechas de varias poesías de los mejores ingenios de España. Zaragoza y Madrid 1670.

10. Ramillete de flores divinas [...] sacados de diferentes autores. ¿Madrid 1670 ?

11. Romances varios de diferentes autores. Amsterdam 1677. 1 ed. más en 1688, en la misma Amsterdam.

12. Varias hermosas flores del Parnaso [...] [de] Antonio Hurtado de Mendoza, Antonio de Solís, Francisco de la Torre y Sebil, Rodrigo Artes y Muñoz, Martín Iuan Barcelo, Juan Bautista Aguilar y otros [....]. Valencia 1680. 
c. Registrando esta restricción progresiva, veamos cuáles recopilaciones impresas por vez primera, y reimpresas, también en el siglo XVII, se reimprimieron en el XVIII:

1. Hystoria del muy noble, y valeroso cavallero, el Cid Ruy Diez de Biuar: En Romances: En lenguaje antiguo. Recopilados por Iuan de Escobar. Lisboa 1605.

25 eds. más en el siglo XVII y 7 entre 1702 y 1757; [también 1818, Londres 1825 y Frankfurt 1828 y en 1829 con venta en París]

Contiene 102 romances, 5 de ellos viejos tradicionales, los demás eruditos y cronísticos, a los que debe su fortuna. A lo largo de su vida tuvo alguna modificación en su contenido.

2. Romances de germanía de varios autores [...] Compuesto por Juan Hidalgo. Barcelona 1609.

3 eds. más en el siglo XVII, todas en Zaragoza, y una en 1779 en Madrid.

3. Lope de Vega, Romancero espiritual para recrearse el alma con Dios. Pamplona 1619.

11 eds. más en el siglo XVII y tres, en Madrid, entre 1720 y 1777.

4. Avisos para la muerte [...] escritos por algunos ingenios de España [...] recogidos y publicados por Luis Ramírez de Arellano. s.1., 1630.

27 eds. más en el siglo XVII y tres entre 1772 y 1777.

5. [Floresta de varios romances sacados de las historias antiguas de los hechos famosos de los doce Pares de Francia, agora nueuamente corregidos por Damián López de Tortajada. Valencia 1646]. No se conocen ejemplares.

6 eds. más en el s. XVII, todas valencianas del Impresor Antonio Bordazar, y 6 entre 1711 y 1764 , todas en Madrid.

En su origen tenía 34 romances, de los cuales 18 viejos juglarescos, entre ellos Marqués de Mantua y Conde de Yrlos. Empezando con una edición valenciana s.a., se agregan otros textos, no solamente carolingios, como los viejos "Amores trata Rodrigo", "Helo helo por do viene / el moro», "Mirava de Campo viejo». Así también en las madrileñas de 1746 e 1764.

En el siglo XVIII, al impresor y editor de Madrid Pedro Joseph Alonso y Padilla, "Librero de Camara del Rey» y "Mercader de Libros», se deben dos de las reimpresiones del Romancero del Cid, dos de las del Romancero espiritual de Lope y tres de las de la Floresta. 
Las recopilaciones que gozaron del mayor número de reimpresiones en el siglo XVIII resultan ser el Romancero del Cid de Escobar y la Floresta de Tortajada, el uno gracias a sus textos 'eruditos' sobre el héroe nacional, y el otro en virtud de la temática en él dominante, la carolingia, con una tradición en la épica culta, pero también gracias a la bien trabada narratividad de la mayoría de sus textos y al lenguaje juglaresco más rebuscado y controlado respecto al de los romances viejos de tipo tradicional.

El Diccionario de Autoridades alista entre sus fuentes propiamente el Romancero del Cid de Escobar, y los Romances de germanía; además, bajo la voz «Romancero», remite al «de Lope de Vega a la Passión», o sea el Romancero espiritual. Así que las primeras tres recopilaciones de las cinco que acabo de reseñar en este apartado eran consideradas -por los Académicosautoridades de la lengua; como apéndice del Diccionario (Tomo sexto, 1739) reimprimieron el Bocabulario de Germanía que Hidalgo había ofrecido en su Romancero. Pero, una vez más, Gregorio Mayans se había adelantado: en sus Orígenes de la lengua española, salido en 1737, había apuntado: "Juan Hidalgo, o otro que quiso llamarse assí, en el año 1609 publicó en Barcelona muchos Romances de germanía de varios autores" ${ }^{57}$, y había reimpreso el Bocabulario de Germania en su tratado.

A propósito de romancero e historia de la lengua en Mayans, anoto una impropiedad terminológica del maestro que genera una aparente confusión. En una carta a Cerdá y Rico comunica: «Es increíble lo que me ha contentado el Sr. D. Tomás Antonio Sánchez con la publicación del Romancero del Cid, que tanto enriquece la lengua castellana» ${ }^{58}$. La carta es de diciembre 1779 , año en el cual no resulta impreso ningún Romancero del Cid; tampoco resulta que el benemérito Sánchez haya cuidado la edición de un Romancero cidiano. En cambio, 1779 es el año en que aparece el primero de los tres volúmenes de la Colección de poesías castellanas anteriores al siglo XV de Sánchez, donde se contiene el Poema del Cid, pero con tal título y así denominado a lo largo de los comentarios de Sánchez, con rarísimas excepciones, como en p. 229 donde se le llama «Romance», mientras en la página anterior se informaba de su división en «cantares». Es evidente que Mayans con «Romancero del Cid» se refiere al Poema, teniendo en cuenta además cierta equivalencia de los dos

57. Gregorio Mayans y Siscar, Origenes de la lengua española, en Obras completas, II, cit., p. 378; y vid. Jesús Pérez Magallón, op. cit., p. 269.

58. Gregorio Mayans y Siscar, Epistolario, XVII: Cartas Literarias [...] Estudio preliminar, transcripción y notas por Amparo Alemany Peiró, Valencia, Publicaciones del Ayuntamiento de Oliva, 2000, p. 279; antes en «Correspondencia literaria de D. Gregorio Mayans y Siscar», Revista de Archivos, Bibliotecas y Museos, XIV (1906), p. 224; y vid. Jesús Pérez Magallón, op. cit., p. 266. 
términos romance y cantar no rara y con noble tradición desde las Crónicas alfonsinas y Santillana. En efecto, en la Vida de Cervantes Mayans alude a «los cantares fabulosos, o por hablar más claro, los romances», y lamenta que en la Chrónica General de España de Alfonso tuvieran entrada «los cantares o romances mentirosos, que al principio sólo eran entretenimientos del vulgo ignorante» ${ }^{59}$.

d. De los libros de poesía privativos del siglo XVIII, con romances, voy a examinar solamente el Parnaso español de Juan José López de Sedano y las Poesias selectas castellanas de Quintana. Que esta segunda obra pertenezca al siglo XVIII, como su autor, creo que nadie lo duda ${ }^{60}$.

1. Parnaso español. Colección de poesías escogidas de los más célebres poetas castellanos [...] por López de Sedano. Madrid, 1768-1778, 9 vols. Abre cada tomo un "Prologo", seguido por una «Noticia de los poetas castellanos que componen el Parnaso Español», con numeración romana de sus páginas; cierra el volumen un "Indice de las poesias que comprende [...] con una breve noticia y juicio de ellas.", también con numeración romana de las páginas. Pongo en letra cursiva cierta terminología valorativa reiterada, que por cierto no es toda privativa de Sedano; pero algunas fórmulas parecen serlo, y las repite como para justificar una inclusión, escudándose tras el tópico del deber didascálico.

Vol. I, 1768: Prólogo, p. ii: «Los Cancioneros antiguos son, á la verdad, unos tesoros preciosísimos, á los quales debemos la noticia, y la conservación de las obras de muchos Poetas de los primeros siglos [...] A estos se agregan los Romanceros: Colecciones también muy apreciables en su especie, que con este, ú otros diversos títulos han recogido, y publicado sus Autores, de que tenemos abundante número $[\ldots] »$.

Parece preanunciarse la aparición de los tomos de Quintana dedicados a Cancioneros y Romanceros en la llamada 'Colección Ramón Fernández'. Es evidente el matiz de diferente aprecio entre Cancioneros y Romanceros, «tesoros preciosísimos» los primeros, «muy apreciables» los segundos, con la añadidura «en su especie» como marcando un límite. Encontraremos tal actitud en casi todos los lugares donde aparecen los romances.

59. Gregorio Mayans y Siscar, Vida de Miguel de Cervantes, cit., p. 226.

60. El Cajón de sastre, literato, ó Percha de maulero erudito. Nueuamente corregido y aumentado por D. Francisco Mariano Nipho, Madrid, 1781-1782 [aparecido en 1760-61], en sus seis tomos contiene un par de docenas de romances, casi todos de autor y sacados varios de ellos del Romancero general. Su naturaleza y los humores que lo rigen lo separan de la canónica antología. Vid. Luis Miguel Enciso Recio, Nipho y el periodismo español del siglo XVIII, Valladolid, Universidad, 1956, p. 197-217. 
p. vi: Declara empezar con Boscán y Garcilaso, dejando fuera a los anteriores, salvando "algunas Piezas excelentes».

Juicio, p. xxiv-xxv: "Romance de Lope de Vega Carpio: A mis soledades voy». Es el primero "de su especie» en comparecer, y por lo tanto impone al recopilador esta anotación general sobre el género:

Los Romances Castellanos son el depósitos de las sentencias y los conceptos; así porque fueron por muchos tiempos el metro más común en todos los Poetas, de que tenemos tantas pruebas en las Colecciones de los Romanceros, como por cierta proporción que facilita el verso octosílabo para expresar más llanamente los pensamientos, y franquea la mera asonancia, sin el cautiverio de la rima [...] no se hicieron para grandes asuntos, ni para tratar altas materias.

Lope «fue más feliz que todos» en este género, gracias también a "la natural corriente de su estilo». Aquí el término corriente podría referirse al estilo de Lope, y en general suele ser atributo casi exclusivo del estilo; menos, de la versificación; en algún caso aparece como sustantivo, por ejemplo en el tomo VIII, p. xxvi y xliv. Se encuentra casi solamente en frases sobre formas métricas y estilos 'menores', en particular el romance; lo mismo constatamos con donayre y gracia, en pareja o solos, de mucha mayor difusión.

Vol. II, 1770: Juicio, p. xxiv: Rom. de Quevedo Matraca de las Flores y la Hortaliza: "donayre [...] gracias [...] materias ridiculas [tratadas] con tanto primor».

Vol. III, 1770: Juicio, p. xxii: Rom. de Suárez de Figueroa: «El medio de proporción de esta casta de metros entre los versos largos y cortos, le hace tan capaz y proporcionado de la llanura agradable que goza para explicar toda suerte de conceptos [...]», y repite consideraciones expresadas para el Romance del vol. I.

Vol. IV, 1770: Juicio, p. xviii: cuatro Roms. de Quevedo: La Fenix, El Pelícano, El Basilisco, El Unicornio. "Siguiendo el proyecto de variedad de metros y de asuntos en las Obras de este gran Poeta [...]»; p. xix: «gracia natural, y donayre satírico", "el asunto es de suyo jocoso y festivo». Tiene un interés muy particular la alusión al "proyecto», privativa de los comentarios pertinentes a textos en formas populares como letrillas y sobre todo romances; manifiesta una justificación, casi una disculpa, por haberles dado entrada en el Parnaso, con una transgresión impuesta por lo robusto de esa tradición poética nacional y por los méritos innegables de ciertos textos. La fórmula aparecía ya en el tomo III, p. xix, al comentarse una «Letrilla ó Glosa» de Espinel, y en este IV, p. iii y iv, a propósito de otra Letrilla y de unas Quintillas de Diego Hurtado de Mendoza. Vid. también en la p. xv. Lo mismo ocurre en el tomo 
IX y último, p. xxxv del Juicio, donde leemos, a propósito de dos textos de Esquilache: "Para diferenciar de metros, y asuntos en nuestro Poeta, como lo egecutamos en todos aquellos de quienes se trata con estension, se incluyen estas dos Letrillas [...]», tituladas también "Endechas». Merece señalarse que en el Juicio del tomo VII, p. ii, volvemos a leer, sobre una Canción de Herrera: "pareció digna de colocarse en este lugar, para variar de especies y metros en nuestro Poeta, como se practica en todos», pero -agreguemoscomo se señala solamente para los metros 'ligeros', en el caso de la Canción doblemente tales: por su naturaleza y como antídoto a «la natural sequedad que se experimenta en casi todas sus [de Herrera] composiciones", como Sedano escribe en la página anterior. La confirmación la hallamos en el tomo VIII, p. xxx del Juicio, donde el comentario a un par de Canciones de Gil Polo se abre así: "Para diferenciar de metros y de asuntos entre los que tratan del elogio de nuestros Poetas [precede el Canto del Turia de Gil Polo y sigue el Canto de Caliope de Cervantes, habiéndose abierto el tomo con el Egemplar Poético de Cueva], y para proporcionar a los Lectores algun descanso y variedad en la lectura continuada de muchas composiciones a un mismo asunto y en un propio metro, ha parecido conveniente interpolar algunas poesías diferentes de cada Autor, que la haga menos fastidiosa [...]»: no se 'presentan' sino que se 'interpolan' tales textos, aptos para "quitar el fastio a los lectores» según decía un recopilador antiguo, Hernando del Castillo. Y Sedano reitera, en p. xxxii, sobre una Letrilla: «Siguiendo el proyecto de interpolar producciones diferentes de los que tratan del elogio de nuestros Poetas, para aligerar su lectura [...]»; y finaliza, en p. xli: «Para concluir $e l$ proyecto de variar de poesías en los Poetas que han llenado la presente idea insertamos esta Cancion [...]», de Espinel. Obviamente, no se trata de criticar a Sedano sino de constatar una actitud 'de escuela' en una de sus formas, diríamos la más evidente por elemental como es la jerarquía de los géneros métricos. Aparte esto, el "proyecto» de variatio de nuestro recopilador tiene su mérito y cumple bien con su función.

p. xxii: Rom. de Angélica y Medoro de Góngora: «No tienen en su linea menos estimación los Romances que las Letrillas de este Autor [...] son de los mejores que se encuentran entre la prodigiosa abundancia de ellos, en que es única la Lengua Castellana.» Apreciación indudable y al mismo tiempo justificativa.

p. xxiii: «Romance inédito: Arrimado á un Sauce verde»: «aunque de corta extensión, se puede hacer lugar entre los mejores Romances de la Lengua»; en p. xxiv, sobre las Octavas que con el Romance componen una especie de Écloga, observa: «contiene más fuerza y nobleza en las expresiones, y diferente 
grandeza y magestad en el metro». Quedan marcadas la diferencia de género y la inferioridad del romanceril.

Vol. V, 1771: Juicio, p. xiii: Rom. de Alonso de Ledesma «En el Tribunal Divino": "Para continuar el sistema de variedad de metros $y$ de asuntos entre nuestros Poetas [...]», "el presente Romance [...] tiene el mérito de la pureza y solidez de la doctrina, en cuanto admite la calidad y extensión de estas composiciones, y el facil modo de explicar los pensamientos, junto con su natural fluidez y limpieza de estilo». Elogios, sin duda, pero precedidos por la fórmula justificativa y unidos a la indicación de los límites del género para asuntos altos. Sin embargo, es inevitable la entrada de dos Romances de Ledesma y de tres de Paravicino, cuyo asunto no es por cierto ni ligero ni menos aun festivo.

p. xv: Rom. de Ledesma «En el telar Virginal»: «blando estilo [...] limpia frase».

p. xx: Rom. de Hortensio Paravicino A la Santa Cruz.

p. xx: Rom. de Paravicino La Secuencia del Santísimo Sacramento: «limpieza de estilo [...] dulzura de expresiones» (p. xxi), donde el segundo témino es de los más abusados en todas la notas críticas ${ }^{61}$.

p. xxi: nota al Rom. de Paravicino Al Santísimo Sacramento: "lo natural y corriente del estilo».

Vol. VI, 1772: dedicado a las Tragedias. En los comentarios críticos, en particular en los relativos a la Isabela y a la Alejandra de Lupercio Leonardo de Argensola, van parejas las censuras por el exceso de muertes y el de la variedad de metros, incluyendo éstos también los de tradición popular, del todo impropios de la «gravedad» del género trágico.

Vol. VII, 1773: Prólogo, p. iv: «uno de los principales fines del proyecto [...] es el desterrar el mal gusto [...] con la inutil y viciosa producción y lectura de Romances, Comedias insulsas, estravagantes amoríos y todas las demás especies de poesía popular» que pervierten las costumbres y hacen malgastar el tiempo. La alusión a "poesía popular» nos lleva a pensar que Sedano se refiera a romances de ciego y jácaras. Asoma, irrefrenable, un justificado disgusto y no sorprende que el primer blanco sean los romances. Juicio, p. xv: Rom. de Góngora Fábula de Leandro y Hero, definida

61. Y no por el solo Sedano, en su siglo y parte del siguiente. Bien define la particular semántica de este término clave el Diario de los literatos de España, IV, 1737 [pero 1738], p. 15, resumiendo un punto de la Poética de Luzán recién salida y que reseńa muy ampliamente: "[...] la belleza, aunque agrada al entendimiento, no mueve al corazón; al contrario la Dulzura, siempre deleyta, y siempe mueve los afectos, que es su principal intento.» Una enjundiosa historia de 'dulzura' desde la época clásica traza Russel P. Sebold, Lirica y poética en España, 1536-1870, Madrid, Cátedra, 2003, pp. 507-523. 
«burlesca»: «Los Romances, y demás poesías de versos cortos de este Poeta, llevan conocida ventaja a todas sus composiciones, [...] las burlescas tienen un mérito particular sobre todas.»

p. xvi: Rom. de Góngora Fábula de Piramo y Tisbe, «Burlesca». Significativa la motivación, amén de la fórmula: «se ha insertado [...] para demostrar la variedad de estilos de este Autor, pues él solo [el Rom. de Píramo] entre todas las Poesías que compuso de esta especie, participa de los vicios de la hinchazon y afectada cultura, cuya introducion se le debe a nuestro Autor».

p. xvii: 'Rom.' de Góngora Noble desengaño [hexasilábico]: «Siguiendo el orden de la variedad de metros, $y$ de asuntos en este Poeta se incluye el presente Romance de redondilla menor, que es de los más apreciables». Es la fórmula acostumbrada para justificar la entrada de un romance.

p. xvii: 'Rom.' de Góngora De amor con intercadencias [octosilábico, y con un verso corto como estribillo]: "Así como las poesías burlescas de este ilustre Poeta llevan la ventaja a las demás, las Letrillas la llevan a todas, y entre ellas la presente», apreciando "donayre [...] festivo género».

p. xvii: 'Rom.' de Góngora La vida del muchacho [hexasilábico]: «Entre las Letrillas más graciosas, y delicadas se señala el presente Romance”; p. xviii: "naturalidad [...] donayre [...] sencillez del metro".

p. xviii: «Romance al mismo propósito. De incierto autor» [es Hermano Perico]: "gracias y donayres [...] limpieza y sencillez del estilo y del metro".

p. xxii: Rom. de Anastasio Pantaleón de Rivera Fábula de Alfeo y Aretusa: «burlesca».

p. xxii: Rom. del mismo Pintura de si mismo a una dama: burlesco: «limpieza del lenguage, y corriente del metro».

p. xxii: Rom. del mismo Fábula del Fénix: «burlesca», «donayre y gracia».

p. xxxiii: Rom. de Luis de Ulloa Pereyra Queja al Conde-Duque: «la natural corriente y dulzura del metro».

Vol. VIII, 1774: Juicio, p. xvi: Rom. de Quevedo Boda y acompañamiento del campo.

p. xvii: Rom. de Quevedo Visita de Alejandro a Diógenes: «gracioso género de invenciones con el fin de burlarse», "donayres».

p. xx: Rom. de Francisco López de Zárate «Bien pueden poner diez años»: "Para demostrar las diferencias de estilos en este Autor, como se practica en todos los demás, se incluye el presente Romance, que aunque no contiene grán mérito en su materia por ser amatoria[...]». Fórmula de justificación y modestia del tema.

p. xx: Rom. del mismo Para festejar a Filis: más o menos repite la observación anterior.

p. xxviii: nota al 'Rom.' de Francisco de Borja, príncipe de Esquilache, «Estaba 
la hermosa Filis» [este Rom. y el siguiente son octosilábicos, pero con partes hexasilábicas y el segundo con alguna variación de metro]: «Para variar de metros y composiciones en este autor, como en todos, se incluyen estos dos de sus Romances, que llamó Letrillas por los Estrambotes o Estrivillos con que los solía adornar y concluir con mucha delicadeza y dulzura, como lo egecuta en el presente, ayudado de la natural limpieza y corriente de su estilo.». Las dos fórmulas, «la natural corriente» y la de justificación, se repiten unas páginas después al comentar dos Endechas del mismo Esquilache: "Para diferenciar de metros, y asuntos en nuestro Poeta, como lo egecutamos en todos aquellos de quienes se trata con estensión» (p. xxxv).

p. xxviii: 'Rom.' del mismo «Hacen paces dos arroyos» [vid. el anterior].

Vol. IX, 1778: Juicio, p. xxxiv: Roms. de Esquilache «Dete el Cielo, hermosa Filis» $\mathrm{y}$ «Verdes Alamos del Tajo»: «La dulzura y pureza del estilo de este Poeta, se conoce más bien en sus Poesías de versos cortos, y en particular en estos Romances, que reducidos a argumentos sencillos, e imágenes simples $y$ naturales, desempeñan el fin para que solo han debido usarse estas composiciones." Reitera la limitación temática, marcada como norma con ese «han debido usarse», que suena a censura de usos 'impropios'.

Sedano selecciona en total 26 Romances en sentido estricto, más 6 con variaciones métricas, en ocho de los nueve tomos, de los cuales los tres primeros contienen un solo romance cada uno; los volúmenes que más contienen son el IV con Quevedo y el VII con Góngora, seis en cada uno. La presencia de un solo texto, de tema profano, y en el primer volumen, del muy elogiado Lope de Vega romancista, podría motivarse con el proyecto quizás ya en marcha de parte de Cerdá, inicial colaborador de Sedano para el Parnaso, de publicar la imponente Colección de las obras sueltas, assi en prosa como en verso, de don Frey Lope Félix de Vega Carpio, Madrid, Sancha, 17761779, en 21 vols. De ellos, el XV contiene entre otros textos el Romancero espiritual, pero con esta nota: «Se omiten los romances, por haberlos dado en las Rimas sacras (tomo XIII); se da una lista de ellos, con referencia a la página de este tomo XIII, donde se encuentran»; y el XVII acoge "Varios versos», entre los cuales «los tomados del Romancero general».

A propósito de Cerdá, es oportuno recordar que fue uno de los discípulos más predilectos de Mayans, de un Mayans que acaso fue el primero en sugerir la realización de un «Parnaso» español seleccionado con método y con escrúpulo filológico, requisitos que no son propiamente los del Parnaso ${ }^{62}$,

62. En Emilio Cotarelo y Mori, Iriarte y su época, Madrid, Sucesores de Rivadeneyra, 1897, p. 165-180, un relato gustoso de las censuras recibidas por el Parnaso, justificadas 
que muy pronto -demasiado quizás- fue obra del solo Sedano; obra que en cualquier caso gozó de amplia fortuna durante muchos decenios ${ }^{63}$.

2. Poesías selectas castellanas desde el tiempo de Juan de Mena hasta nuestros dias. Recogidas y ordenadas por D. Manuel Josef Quintana. Madrid, Gómez Fuentenebro y Compañía, 1807. Nueva edición aumentada y corregida: Madrid, M. de Burgos, 1830, 3 vols. Ed. definitiva: Tesoro del Parnaso español o Poesías selectas [...], Paris 1838; reimpresión Paris, Baudry, 1861 , en un volumen único, el XV de la "Colección de los mejores autores españoles", que utilizo.

De p. 173 a p. 216 hay una sección dedicada al Romancero anónimo. Sobre todo por su amplitud, es una novedad importante, aunque ya el Parnaso de Sedano presentaba algún texto de «autor desconocido». Se articula en cinco «Partes»:

$1^{\mathrm{a}}$. «Romances moriscos», 18

$2^{\text {a } . ~ « R o m a n c e s ~ p a s t o r i l e s », ~} 19$

$3^{\text {a }}$. "Romances heroicos», 15 [los del Cid se declaran «sacados del Romancero del Cid», o sea el de Escobar]

$4^{\mathrm{a}}$. «Romances cortos y letrillas», 25

5 a. «Romances jocosos», 7.

Sigue Lope de Vega, con poco más de setenta páginas, donde van 3 Romances; y después, con Romances, Góngora (20 octosilábicos y 12 entre cortos y letrillas), Quevedo y Esquilache.

En la parte final, de p. 423 en adelante, se presenta -abierta con Luzánla poesía del siglo XVIII, después de una bien argumentada Introducción sobre sus virtudes y defectos, acarreados en buena parte porque el numen poético acabó obscurecido por el espíritu crítico del siglo. Los romances que se seleccionan son 8 de Meléndez Valdés y 3 de Iglesias. Obvia la presencia de Nicolás Moratín, pero sin romances, «los gallardísimos romances moriscos y caballerescos» según el elogio de Menéndez Pelayo, que indicaba en ellos lo único que ya se solía -y se debía- leer de este autor ${ }^{64}$.

La primera edición de la obra había sido publicada en 1807 y había tenido después otras salidas con modificaciones. Además Quintana ya en 1795 y

aunque dentro de una dura polémica con Iriarte.

63. Françoise Étienvre, «Entre Mayans y Luzán: la necesidad de un Parnaso», Bulletin Hispanique, 109, 2007: La Formation du Parnasse Espagnol XV-XVIII Siècle, p. 685-708 [690 y 708] y François Lopez, «La generación de 1780 y sus parnasos», ibid., p. 709-747 [716 sigs.].

64. Op. cit., p. 284. 
1796 había publicado Poesías escogidas de nuestros cancioneros y romanceros antiguos, que eran los vols. XVI y XVII de la llamada 'Colección de D. Ramón Fernández'. El verdadero editor de la parte mayor de la Colección era Estala, siendo el tal Fernández un cirujano aficionado a las letras y que financió los seis primeros volúmenes de la obra ${ }^{65}$. Quintana aprovecha su importante trabajo primitivo, reelaborándolo y enriqueciéndolo, pero sin modificar radicalmente los criterios de selección textual, afines a los de Sedano ${ }^{66}$ en cuanto criterios de un intelectual de recia formación neoclásica pero -en el caso de Quintana- con una madurez cultural y un gusto suyos propios y excepcionales. Los romances siguen siendo los más o menos cultos de finales del XVI y del XVII, con un enjuiciamiento general amplio y apasionado, pero con comentarios críticos individuales casi ausentes, al contrario de lo que ocurre con los textos de otros géneros, sobre todo los 'altos', de 'verso largo'.

Una buena excepción es el tratamiento crítico que se merece el Góngora métricamente 'menor', rebosante de entusiasmo y elogios hacia un poeta "que conocía tal vez mejor que otro alguno el partido que podía sacarse de esta poesía vulgar [esto no se discute], y que por instinto era llevado a ella; empleaba en los romances todas las fuerzas que tenía, y estas fuerzas eran grandes» (p. 327n). Llega a afirmar, sobre "Amadores desdichados I que seguís milicia tal»: «De llaneza, en fin, de concisión y una exactitud que pudiera llamarse matemática, si cupiera esta denominación en poesía, pocos pasajes se hallarán en la castellana iguales a este de la invectiva contra el amor»(p. 328n.). Y la emoción estética es tal que se ve arrastrado a suprimir en un texto la que juzga una "copla impertinente y pueril [...] para no estropear con ella el más bello pasage de la composición» (p. 328n). En la Introducción ya había proclamado al cordobés «rey» del romance y de las letrillas, según el buen gusto de cualquier siglo pero esencialmente según la buena tradición retórico-crítica de larga parte del XVIII ${ }^{67}$.

65. François Lopez, «La generación», cit., p. 734 sigs.; el art. de José Checa Beltrán cit. infra, en la nota 68 y María Elena Arenas Cruz, Pedro Estala, vida y obra. Una aportación a la teoría literaria del siglo XVIII español, Madrid, CSIC, 2003, p. 155-191.

66. El cual Sedano (¡o Cerdá?) en el Prólogo al vol. I del Parnaso había dado ya gran relieve propiamente a Cancioneros y Romanceros «antiguos» como «tesoros preciosísimos» de textos poéticos de autores, con un desinterés implícito -en principio- por los textos anónimos (vid. supra).

67. José María Pozuelo y Rosa María Aradra, Teoría del canon, cit., y también Inmaculada Urzainqui, "La crítica literaria", cit., p. 519-559. 


\section{BULLETIN HISPANIQUE}

\section{Se aprecian renglones como los siguientes:}

[...] componiéndose más bien por instinto que por arte, los Romances no podían tener el aparato y la elevación de las odas de León, Herrera y Rioja. Pero ellos eran propiamente nuestra poesía lírica [...] pintaban felizmente las costumbres moriscas y las pastoriles, y conservaban en la memoria del vulgo las proezas del Cid y otros campeones [y aquí captamos al biógrafo del Cid para las Vidas de españoles célebres y al lector del Romancero de Escobar] [...] Hay en ellos más expresiones bellas y enérgicas, más rasgos delicados e ingeniosos que en todo lo demás de nuestra poesía (p. 20).

Sigue un remite una vez más a los romances moriscos y a los pastoriles, que no nos permite compartir la hipérbole de la apreciación ${ }^{68}$. No se callan los defectos, que atribuye al éxito excesivo y sobre todo al creciente mal gusto que por largo tiempo oscureció el horizonte de la poesía castellana.

68. Que venía de lejos, entroncando con la idea de una influencia determinante de la poesía árabe en los orígenes del romancero, sugerida propiamente por los romances moriscos y su pretendida antigüedad. Más en general, detrás de los elogios extremosos de Quintana en favor del romancero y en detrimento hasta de «todo lo demás de nuestra poesía» es inevitable captar rasgos de la polémica de finales de siglo entre conservadores y novatores, que bien ilustra exactamente a propósito de la llamada "Colección Ramón Fernández» José Checa Beltrán, «El libro: La Colección de Poetas Castellanos (1786-1798)», en Joaquín Álvarez Barrientos, ed., Espacios de la comunicación literaria, Madrid, CSIC, 2002, p. 109-128. Una tardía y muy agria reseña al trabajo de Quintana, fechada en Cádiz 24 de agosto de 1823 y publicada en El Criticón, núm. 6 de 1859, p. 5-37, dedicó Bartolomé José Gallardo: «Reparos críticos al Romancero y Cancionero publicado por D. Manuel Josef Quintana en la 'Colección de poesías castellanas' de D. Ramón Fernández». El singular que Gallardo adopta en su título, en contra del plural con que se ufanan los dos tomos de la Colección, refleja su primera dura crítica, o sea el haber Quintana utilizado como fuente el solo Cancionero general de Hernando del Castillo y el solo Romancero general en una edición de 1604, frente a las decenas de recopilaciones de ambos tipos que el mismo Gallardo había podido manejar; y haberlos usado con poco respeto de la lección de los textos, e incluso de su integridad en más de un caso. Humores en parte análogos, pero mucho más blandos, captamos en una bien informada carta de octubre de 1817 de Leandro Fernández de Moratín, de Montpellier, a Juan Antonio Melón: «Dile a D. Julián que el Romancero general está ya muy saqueado: Quintana escogió de él lo que le pareció mejor, y lo imprimió en un tomo o dos, que forma parte de aquella colección de poetas que empezó D. Ramón Fernández; y que después el mismo Quintana volvió a hacer en él una rebusca, y la incluyó en la colección de Poesías españolas escogidas, que corre en tres tomos; y a mayor abundamiento, esta colección se acaba de reimprimir en Perpiñán. Resulta, pues, que lo mejor que hay en el Romancero se ha impreso tres veces, de pocos años a esta parte»; sería preferible una buena selección de los Cancioneros, concluye: vid. Epistolario, edición, introducción y notas de René Andioc, Madrid, Castalia, 1973, p. 380. 
Cuando Quintana volvía a leer estas páginas, confirmándolas para las reediciones de su Tesoro, eran los años en que salía en Viena la Silva de romances viejos de Grimm (1815) y en que Durán iba publicando los tomos que después formarán su magno Romancero general ${ }^{69}$. Confirmaba Quintana su colocación cultural dentro de la ortodoxia del siglo apenas concluido. Y que no suene esto a crítica ni a ignorancia por parte de Quintana de las obras que acabo de citar y, quizás, de las antiguas recopilaciones. En cuanto historiador y antólogo de la poesía, priva en él -como en los demás de su época propia- la finalidad pedagógica; sobre el 'gusto' del individuo se imponen el 'buen gusto' de escuela y el deber de ofrecer y comentar modelos de arte de la poesía en sus diferentes categorías más que documentos de su historia. Simplificando mucho, podemos decir que -en este aspecto- hay una continuidad casi sin interrupción de Santillana a Luzán y a Quintana, debiéndose distinguir en los dos últimos obviamente la reivindicación de las tradiciones poéticas nacionales, que es uno de los pocos ámbitos donde luces del siglo XVIII se continúan y funden con brillos románticos.

\section{ApÉNDICE}

La referencia al canto de romances en las danzas de Asturias, que leemos en la Poética de Luzán, parece independiente de la contenida en la Carta VIII de Jovellanos a Ponz. Pueden valer las consideraciones siguientes:

- remite explícitamente a la danza prima, denominación ausente en Jovellanos, como suelen subrayar sus comentaristas ${ }^{70}$;

- aparte el rasgo métrico, de canto y danza se da la genérica localización

69. Ténganse en cuenta, asimismo, unas fechas y unas obras fuera de España, en los decenios que se han reseñado: 1735, Inquiry into the Life and Writings of Homer, de Thomas Blackwell, donde los romances moriscos son citados como ejemplos de poesía popular; 1765, Reliques of Ancient English Poetry, de Percy, con un par de romances sacados de las Guerras de Granada de Pérez de Hita y una explicación de los rasgos métricos del género; 1778-79, Volkslieder de Herder, una vez más con muestras de las Guerras; 1783, una libre traducción de la colección cidiana de Escobar en la «Bibliothèque Universelle des Romans»; 1801, Ancient Ballads from the Civil Wars of Granada, de Thomas Rodd; 1803, Der Cid nach spanischen Romanzen, de Herder. Más información sobre éstas y otras obras en Ramón Menéndez Pidal, Romancero Hispánico, cit., II, p. 239-269.

70. En vista del texto de Luzán, resulta en exceso tajante la segunda parte de la afirmación de José Caso González, ed., Las cartas, cit., vol. II, p. 31n: «Jovellanos no utiliza nunca el adjetivo prima, lo que prueba que no lo conocía, que no se utilizaba en su tiempo y que es un invento posterior.» 
en las montañas de Asturias sin especificaciones ulteriores, mientras que en Jovellanos la descripción es muy amplia y bipartida, sobre la base de que "cada sexo forma las suyas [danzas] separadamente» y «tiene su poesía, su canto y sus movimientos peculiares»"

- en la danza asturiana -informa la Poética- "se usan todavía» los antiguos romances que cantaban «lances de amor y de caballería». Jovellanos, como los informantes sucesivos, distingue: hay por un lado las "danzas varoniles», cuyos romances "suelen ser de guapos $\mathrm{y}$ valentones [las jácaras], pero los estrambotes [o sea los estribillos] contienen siempre alguna deprecación a la Virgen, a Santiago, San Pedro u otro santo famoso, cuyo nombre sea asonante con la media rima general del romance» ${ }^{72}$, con colas de vítores que eran preludio a la ineludible conclusión «a palos» entre pandillas rivales; por otro lado están «las danzas de las asturianas» que «ofrecen ciertamente un objeto, si no más raro, a lo menos más agradable y menos fiero» respecto al de los varones. Poco después llega la famosa cita del verso «Ay un galán de esta villa», Romance cuyo tema se adhiere más bien a los «lances de amor y de caballería» de Luzán, como se confirma cuando Jovellanos agrega que «El objeto de esta poesía es ordinariamente el amor», aunque a veces entren «sátiras e invectivas» que aduce y comenta con gracia $^{73}$. En efecto, el Romance citado antes aparece entre los «cantares de mujeres", distintos de los "de hombres», en los apuntes de un recolector de la primera mitad del Ochocientos ${ }^{74}$;

- el remite de Jovellanos al citado verso del Romance tradicional asturiano es algo confuso, consecuencia probable de lo abigarrado y confuso del texto del Romance según aparece en las versiones que conocemos, a partir de las transcritas a finales del siglo XVIII y comienzos del siguiente. El mismo Jovellanos admite que «Los estribillos con que

71. Gaspar Melchor de Jovellanos, Obras en prosa, cit., p. 146. José Caso González, ed., Las cartas, cit., II, p. 32-33n, tiende a suponer la coexistencia de danzas por separado y de danzas mixtas, probablemente más antiguas y que iban siendo prohibidas en favor de las primeras, apreciadas por un Jovellanos que "se deja llevar de un apriorismo: la mezcla de sexos conduce a la perversión de costumbres", ajena a un pueblo 'inocente'. Se podría pensar, entonces, que la referencia en Luzán refleja el estadio originario, el de la danza mixta: sería un apoyo a la autonomía y notable anterioridad de esa referencia respecto al texto de Jovellanos.

72. Ibid., p. 147.

73. Ibid., p. 149 sigs.

74. Vid. Jesús Antonio Cid, op. cit., p. 98. 
se alternan estas coplas son una especie de retahíla que nunca he podido entender; pero siempre tienen sus alusiones a los amores y galanteos» ${ }^{75}$. Lo curioso es que el verso en cuestión completa la información siguiente: en la danza de las mujeres asturianas «su poesía se reduce a un solo cuarteto o copla de ocho sílabas, alternando con un largo estrambote, o sea estribillo, en el mismo género de versos, que se repite a ciertas y determinadas pausas", y de tal estrambote o estribillo cita el primer verso ya dicho ${ }^{76}$. Acabamos sospechando una especie de inversión en la dimensión del texto, donde una poesía que «se reduce a un solo cuarteto» alterna con «un largo estrambote, o sea estribillo» consistente en aquella «especie de retahíla» de dificil comprensión, que es propiamente el texto conocido del Romance. Es anomalía que ya ha sido notada ${ }^{77}$ y que no encontramos en la descripción de las «danzas varoniles».

Los rasgos de la cita en la Poética indican su muy probable autonomía, a pesar de su extremada brevedad respecto a las amplias y detalladas páginas de Jovellanos, que tenían finalidad bien distinta. La cita de la Poética es estrictamente funcional al contexto técnico, el capítulo sobre consonantes, asonantes y versos sueltos: aporta un ejemplo interesante de curiosa supervivencia de una forma métrica antigua asociada al canto en la danza y gracias a éste conservada. Tal testimonio oral contemporáneo enriquece el documento escrito antiguo aportando el estribillo, notoriamente omitido en manuscritos e impresos del XV, XVI y XVII; la especie artística dentro de la cual sigue usándose y se transmite el romance con estribillo es la danza prima, que solamente la Poética nombra con tal definición.

No es posible excluir que este parrafillo de la Poética, que tanto nos intriga, pudiera haber sido un añadido de Llaguno. En tal caso, ¿pudo Llaguno haber tenido a la vista el texto de Jovellanos o haber sabido algo de él, precisando más gracias a algún informe oral? Tampoco podemos excluirlo. Téngase en cuenta que conocemos muy imperfectamente las andanzas de las cartas de Jovellanos a Ponz, nunca utilizadas por el destinatario, muerto en 1792. Redactadas a partir de 1782, quizás retocadas por el autor en los ańos siguientes, mientras Llaguno preparaba la reedición de la Poética, fueron

75. Gaspar Melchor de Jovellanos, Obras en prosa, cit., p. 151.

76. Ibid., p. 149.

77. Ibid., p. 149n. 
reorganizadas en 1794 para una publicación que nunca se realizó; no hay confirmación de salidas sueltas en periódicos. En carta del 27 de octubre de 1792 a Carlos González de Posada comunicaba Jovellanos haber asistido en Candás a "la más magnífica danza de hombres que había visto yo en mi vida» ${ }^{78}$. Caso González parece suponer una relación con lo referido en la carta a Ponz ${ }^{79}$. De ser así, el informe en la carta a Ponz sería un agregado tardío. Lo dudo, porque Jovellanos en la carta a Posada deja entender que había visto ya esa clase de danzas.

78. Gaspar Melchor de Jovellanos, Obras, I: Epistolario, ed. de José Caso González, Barcelona, Labor, 1970, p. 84.

79. José Caso González, "Ensayo de reconstrucción del romance ¡Ay! un galán de esta villa", Archivum, IV, 1954, p. 385-422 [387n].

Joaquín Álvarez Barrientos, "Poesía popular e imagen nacional, según Meléndez Valdés» y Marieta Cantos Casenave, "Doña Elvira y la dignificación del romance en el siglo XVIII", ambos en Juan Meléndez Valdés y su tiempo, Mérida, Editora Regional de Extremadura, 2005, p. 305-316 y 151-161 respectivamente. 